\title{
Financial Assessment and The Impact of Government Incentives on Contract Broiler Farming in Peninsular Malaysia
}

\author{
Zineb Abdulaker Benalywa**, Mohd Mansor Ismail ${ }^{\mathrm{b}}$, Mad Nasir Shamsudin ${ }^{\mathrm{c}}$, and Zulkornain \\ Yusop $^{\text {d }}$ \\ a,b,c,d University Putra Malaysia \\ Jalan Upm, 43400 Serdang, Selangor, Malaysia \\ *Email: zineb_a14@yahoo.com
}

\begin{abstract}
The broiler industry in Peninsular Malaysia has undertaken significant structural changes; mainly there has been a gradual move towards contract farming with an increasing number of broiler farmers working under contract arrangements for commercial firms and integrators. DVS indicated that the broiler contract farming system dominated around $75 \%$ of the domestic broiler production in Malaysia. Private Profitability plays a vital role in the sustainability of the broiler industry. To enhancement the agricultural performance in the country, the Malaysian government has been introduced several policies. Financial profitability is gauged using three agriculture incentives namely Pioneer Status (PS), Investment Tax Allowance (ITA) and Accelerated Capital Allowance (ACA). Though, the lack of effectiveness of the program is still of concern to the agricultural sector given the significance of poultry in Malaysia. The purpose of the study was to determine the extent to which those incentives affect the feasibility of the industry and financially assisting the viability of the project of contract farming in Peninsular Malaysia. Financial evaluation instruments were used to compute the assessment of firm's financial projection mainly, Net Present Value (NPV), Internal Rate of Return (IRR), Payback Period(PBP) and Profitability Index (PI). The questionnaire used as a tool for data collection and a face-to-face interview was organized for the 206 broiler contract farmers as respondents. The result reveals that the stock farmers who involve in contract farming are viable; highly profitable and rapidly recover its initial investment Moreover, with Government Incentives, the majority of stockbreeders gain positively. For instance, with a combination between ACA and PS or/and ACA and ITA, the tendency of high financial viability mostly occur in the broiler investment.
\end{abstract}

Keywords: Broiler contract farming, Government incentives, financial viability, Malaysia

\section{Introduction}

Malaysian broiler industry has been able to transform from a low level to highly commercialized efficient production systems in the relatively short period. From the fact that broiler is the most popular meat and cheapest source of protein among Malaysian people the production output has been increased rapidly. The livestock industry contribution to the gross domestic product (GDP) growth in the Malaysian agriculture showed a rising trend where it rose from $9.1 \%$ in 2006 to $10.7 \%$ in 2015 , mainly the non-ruminant sub-sector [1]. The broiler industry, as an essential part of the non-ruminant sub-sector, has recorded enormous growth, mostly drove by efficient and organized entities in the sector where large business controls a greater share of the market. Contract farming contributes more than $75 \%$ of broiler production in Malaysia [2]. The broiler meat also achieved more than $110 \%$ self-sufficiency in the period from 2009 to 2014 [2]. Broiler meat is the primary source of animal protein in Malaysia where the per capita consumption reached almost $50 \mathrm{~kg}$ in 2015 [2]. Fig. 1 shows that broiler production is increasing every year due to higher demand by local consumers and export markets.

In broiler industry, the main cost of production is feed. Feed represents the major cost of poultry production according to [2] which constitute up to $72 \%$ of the total production cost. Fig. 2 indicates the breakdown of the cost of output in 2015; it is clear that feed contributes the highest value with $72 \%$ following by DOC (Day Old Chicken) with $21 \%$. Of the total feed cost, about 95 percent is used to meet energy and protein requirements, around 3 to 4 percent for the main mineral, trace mineral and vitamin requirements, and 1 to 2 percent of various feed additives. [3] Stated that the major obstacles to broiler production are the costive price of feed and the instability of the Day Old Chicks (DOC) prices. 


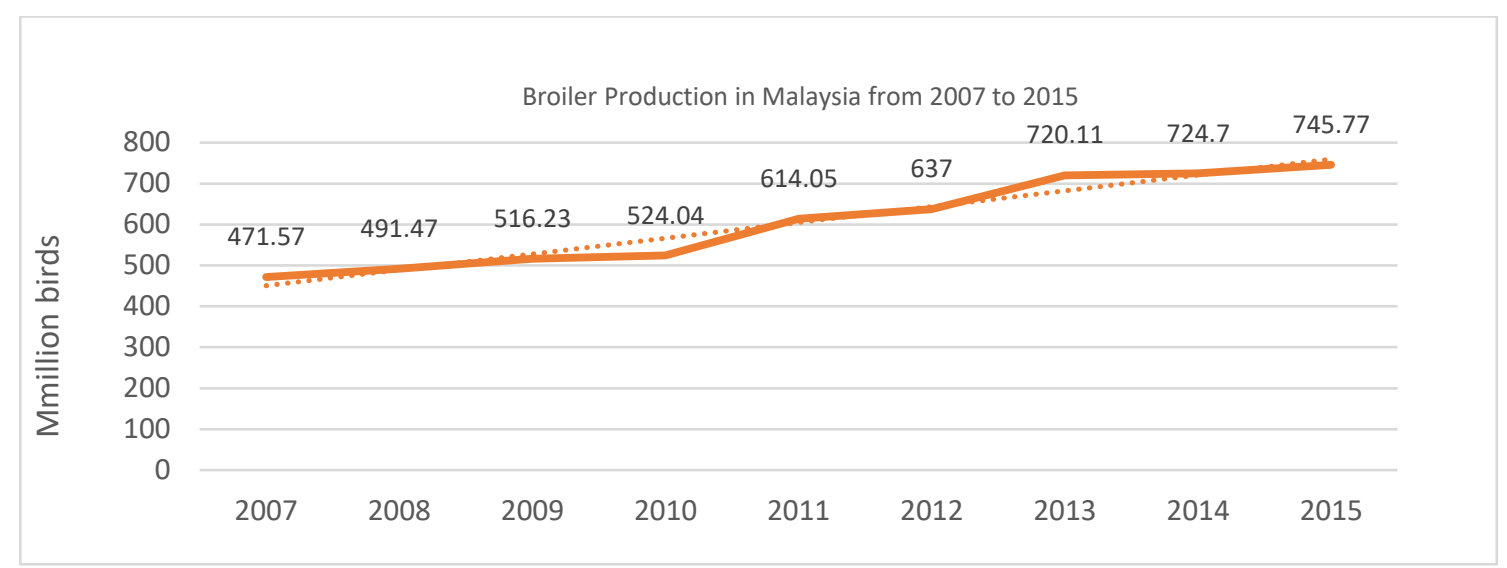

Figure 1. Broiler Production in Malaysia from 2007 to 2015

Source: DVS (Department of Veterinary Statistics, 2015)

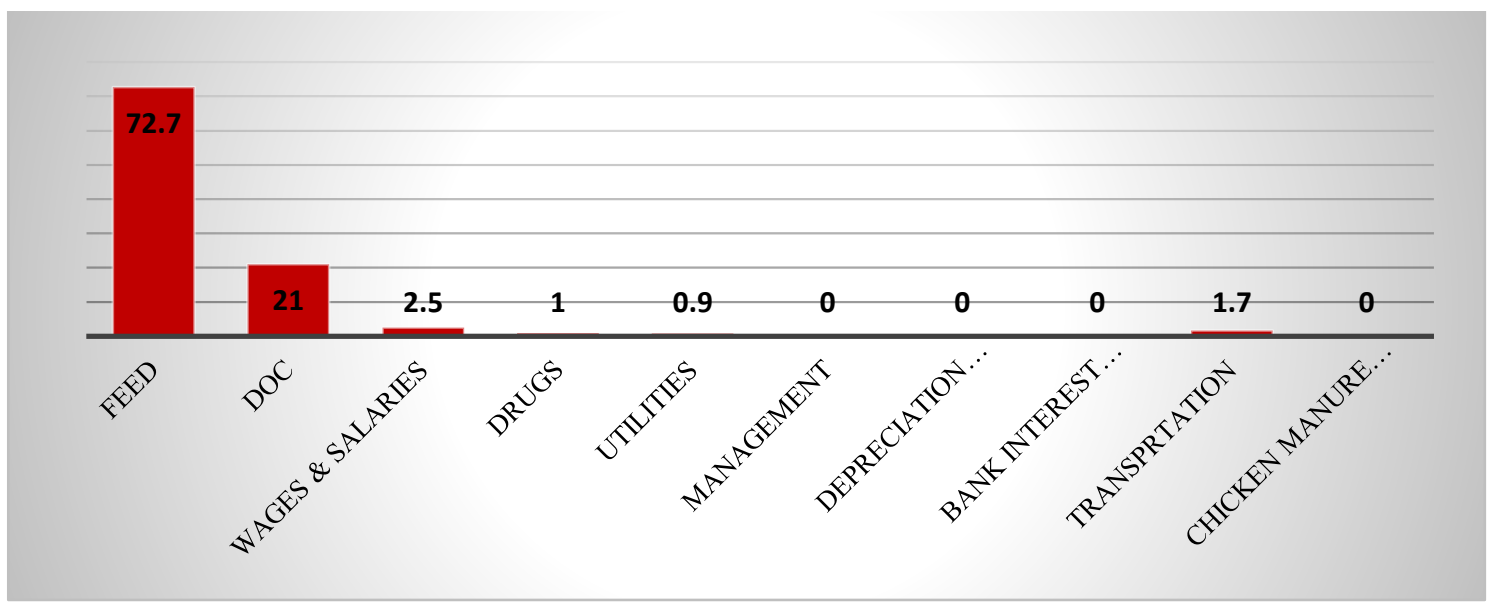

Figure 2 Breakdown of the cost of production in 2015

Sources: DVS (Malaysia Competition Commission, 2015)

Before considering any agriculture project is feasible and sustainable, financial evaluation is compulsory in any agriculture projects. The government should consider policies that will help the industry to survive if the sector is vital for food security. That will ensure accessibility and availability of the commodities. This study emphasis on financial assessment and the approach is to incorporate benefits, all inputs and government incentives aiming at increasing farm profitability. The government incentives evaluated in this study are (1) Pioneer status where a firm enjoys a partial exemption from income tax. A company pays tax on $30 \%$ of statutory income only for five years, starting from its production day (defined as the day of the first sale of chicken. (2) An investment tax allowance ITA; a farm granted an Investment Tax Allowance
ITA is eligible for an allowance of up to $70 \%$ of its qualifying capital expenditure incurred within five years since the date of first qualifying capital expenditure incurred. (3) Accelerated Capital Allowance (ACA); the ACA on the capital investment is to be utilized within the next three years, that is, an initial allowance of $60 \%$ for the first year and an annual allowance of $20 \%$ for the following two years. That is also agreed with [4] who indicated that profit is the core factor in investigating economic enterprises. The current research purposes at evaluating the financial viability of broiler production in Peninsular Malaysia with government incentives (various tax incentives) incorporated in the financial assessment to measure their impact on financial indicators. 


\section{Literature Review}

Dayananda [5] stated that Capital budgeting is the process of deciding investment projects which create in the maximization of shareholder value. Capital budgeting plays a crucial role in any organization's financial management strategy. The analysis provides a mutual understanding of firm's profitability, return, and cost-benefit in the scope of private project evaluation in this study. All the organization must ensure that their decision enhances the competitiveness over its rivalries. Sekwat [6] indicated that Capital budgeting is an integral part in the financial planning and decision making as capital budgeting tools leads better decision making and be able to justify the selection of specific capital investments among competing alternatives.

Net present value (NPV), internal rate of return (IRR), payback period (PBP), and profitability index (PI) are the most used capital budgeting techniques in the public finance literature, e.g., [6]. These methods have been identified as a predominant method and used in many studies, e.g., [7]. NPV describes the amount cash that the firms earn in the project. The negative result of NPV displays that the cost exceeds the benefit which is mean that the project is not economically feasible. Internal rate return (IRR) is one of the commonly employed in assessment, determine the profitability of a single project which is very clear and apparent for the investors to digest. The IRR determines the rate at which capital investment can be adequate and consequently equates the cost of the capital investment to the project' present value [8]. If the value of IRR is positive and higher than the discount rate, it demonstrates that the project is adequate [9]. NPV and IRR, have been supported in the literature [10]. It is agreed that IRR mostly preferred method in larger companies operating in the U.S. NPV was the next preferred method [11]. Payback is a significant indicator to decide the acceptability of an investment project as it determines how fast will recover the cash resource which has been used to finance the project [12].

To encourage investment and enhancement of the potentials of agricultural, manufacturing and services sectors. [13] Has outlined Government incentives. The adequate incentives for agriculture are Pioneer Status (PS), Investment Tax Allowance (ITA), and Accelerated Capital Allowance (ACA). Pioneer Status serves a partial exemption from company's tax. Its incentives offer payment of $30 \%$ tax from statutory income for five years. Investment Tax Allowance grants the agriculture firms to offset the allowance against $70 \%$ from statutory income in the year of assessment, and unutilized allowance will be carried forward to years to come till fully utilized. On the other hand, Accelerated Capital Allowance provides an initial allowance in the first year and about $40 \%$ of an annual allowance. Usually, the conjoined package of Investment Tax Allowance with Accelerated Capital Allowance is used to maximize profit for the agricultural companies.

\section{Materials and Methods}

The study focuses on primary data from questionnaires via a face to face interview with the contract farmers in Peninsular Malaysia. The source of data collection includes essential financial data of input-output costs, farm's initial investment and income statement from farm production reports. Stratified sampling initially used as a sampling method, and the targeted respondents are categorized explicitly for the contract farming. Thus, the study employs about to 204 contract farming.

Capital budgeting techniques applied in this study to analyze the data. Net Present Value (NPV), Internal Rate of Return (IRR), Profitability Index (PI), and Payback Period (PBP). The discount rate is imposed to determine a time value of money to the cost of capital as $10 \%$ during the project assessment. Along with an essential evaluation of financial appraisal, the adoption of government tax incentives in the financial projection is also implemented to find the impact of those variables. The tools of financial analysis are shown in the following mathematical expression below:

Net Present Value (NPV) is also known as discounted cash flow technique. The positive result of NPV indicates the project is financially viable and accepted. The formula below is used in calculation:

$$
N P V=\sum_{t=0}^{N} \frac{C F_{t}}{(1+r)^{t}}
$$

$$
\begin{aligned}
& \text { Where, } \\
& \text { CF = Cash Flow } \\
& \mathrm{r}=\text { Discount Rate } \\
& \mathrm{t}=\text { Time }
\end{aligned}
$$

Internal Rate Return (IRR). The IRR defined as the discount rate when the net profit value of the project is equal to zero. IRR shall be compared to the company's cost of capital. The rate means the project must surpass to create positive shareholder wealth.

$$
N P V=\sum_{t=0}^{N} \frac{C F_{t}}{(1+I R R)^{t}}=0
$$

Where,

$$
\begin{aligned}
& \mathrm{CF}=\text { Cash Flow } \\
& \mathrm{r}=\text { Discount Rate } \\
& \mathrm{t}=\text { Time } \\
& \text { IRR = Internal Rate of Return }
\end{aligned}
$$

Profitability Index (PI) or Benefit Cost Ratio (BCR) The Profitability Index known as the present value of the project's cash flows divided by the cost. PI describes the potential profit from each money invested. 


$$
P I=\frac{P V \text { of future cash flows }}{\text { Initial cost }}=\frac{\sum_{t=0}^{N} \frac{C F_{t}}{(1+r)^{t}}}{C F_{0}}
$$

Where,

$\mathrm{CF}=$ Cash Flow

$r=$ Discount Rate

$\mathrm{t}=$ Time

$\mathrm{PV}=$ Present Value

Payback Period - Payback period is the expected number of years required to recover the initial investment. The payback period can be calculated by:

$$
\text { PaybackPeriod }=\frac{\text { Initial Investment }}{\text { Periodic Cash Flow }}
$$

\section{Results and discussion}

The average economic attributes of the farms presented in Table I. Accordingly, the total broiler farms are 206. The number of day-old chicken around 52153.73 per cycle and the overall production is about 49914.73 per cycle. Average selling price at the farm gate is RM 4.32 per $\mathrm{kg}$, and the average weight of the broiler is $2.18 \mathrm{~kg}$.

Table 1. The Average Economic Attributes of the Farms

\begin{tabular}{|c|c|}
\hline Variables & Values \\
\hline Number of day old Chick (DOC) per cycle & 52153.73 \\
\hline Total Production per cycle & 49914.73 \\
\hline Price of DOC (RM) & 1.56 \\
\hline Selling price per kg(RM) & 4.32 \\
\hline Mortality Rate (\%) & 4.29 \\
\hline Average Weight of Broiler (kg) & 2.18 \\
\hline
\end{tabular}

Source: Author calculation based on data collection 2015

NPV results in Fig. 3 shows an accepted projection to the financial assessment since the outcome provides positive cash to the initial prediction and all incentives schemes. Therefore, the farmers may generate earnings and the project is financially viable. Where the government tax incentives applied, the values of NPV are improved. Among the tax incentive scenarios, a combined tax incentive between ITA and ACA is better than other schemes. Thus, Broiler contract farmers should explore ITA on ACA tax incentives scenario in their farming to obtain better viability.

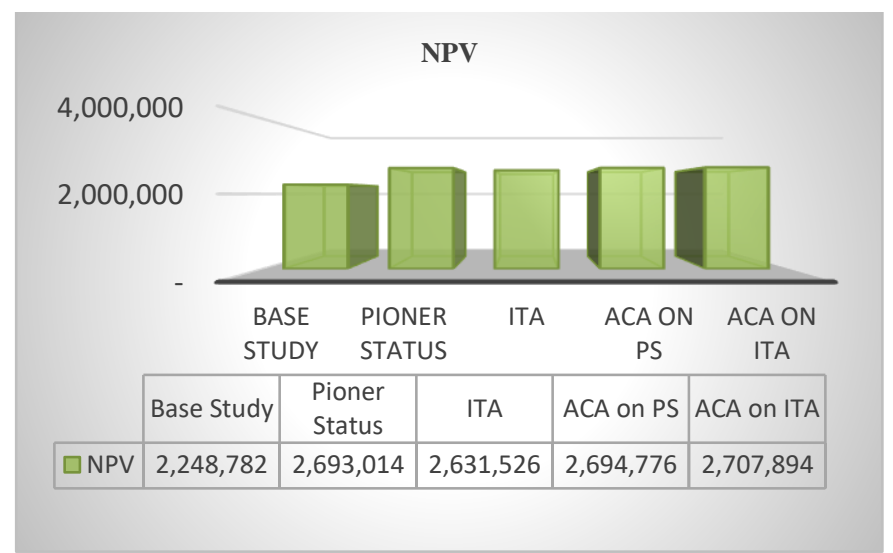

Figure 3. Net Present Value results

Internal Rate of Return (IRR) results is shown in fig 4. The non-tax incentive (base study) of IRR results in $42 \%$, indicating the visibility of the project since it is higher than discounted factors $10 \%$. Once the tax incentives granted the value of IRR improves project's viability. To provide higher income, the farmers should apply the ITA on ACA tax incentives since the rate found as the most viable among other tax incentive scenarios; it can be concluded that the cash flow of this business for the future income will drag positive outcome and reduce risk factors of the project.

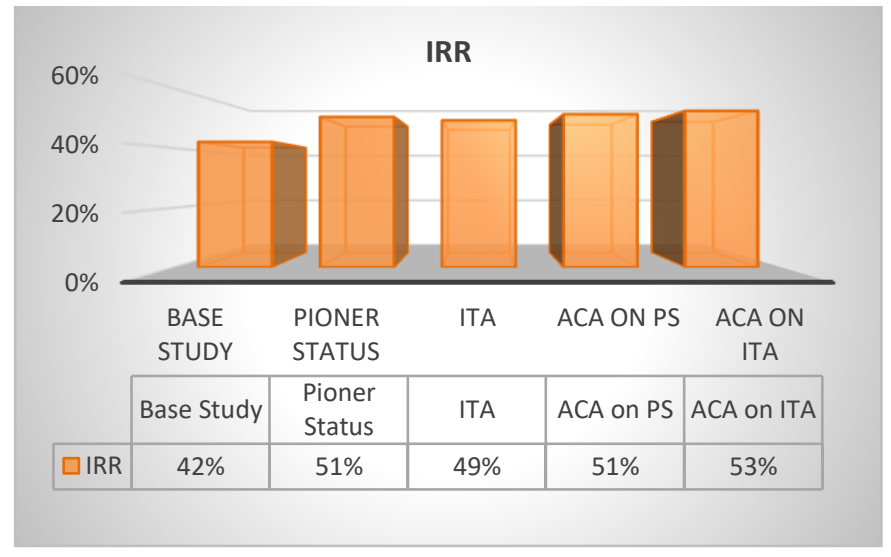

Figure 4. Internal Rate of Return results

Results of Profitability Index PI with a base period and tax incentives scenarios are presented in fig. 5 the value of the profitability index of (base study) is (2.75) it means that the project can earn 1.75 cents per $1 \mathrm{RM}$ invested in the project. Moreover, the respective of tax situations, the tax incentive projects display better feasibility; the ITA on ACA is the most profitable project with a gain of RM 2.11 per RM1 invested on cash return. Farmers are still considered as an ideal investment since the value of PI reveals more than one which indicates that the project is more than just breaking even. 


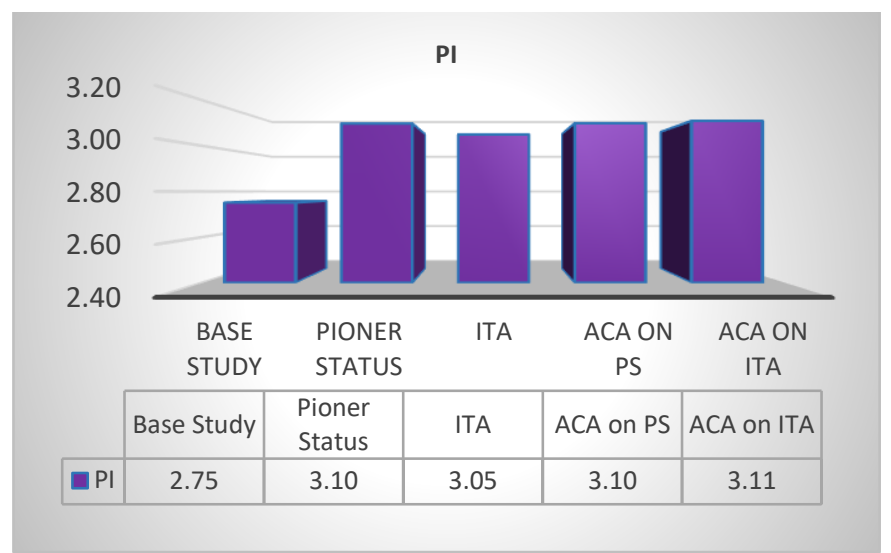

Figure 5. Profitability Index results

Comparison between the effects of non-tax and government tax incentive scenarios for a payback period of broiler contract farming is indicated in fig. 6. The PBP indicator of non-tax incentive (base study) shows 2.32; this means that the project can recover its invested capital under two years of operation. Depending on capital invested, this less than most agricultural projects which require more than five years to recoup their capital investment. According to the tax incentives, The ACA on ITA tax incentive shows the least payback period of about 1.7 years of retrieval of invested capital. Therefore, the need for farmers to employ this scenario is encouraged for enhanced higher income flows.

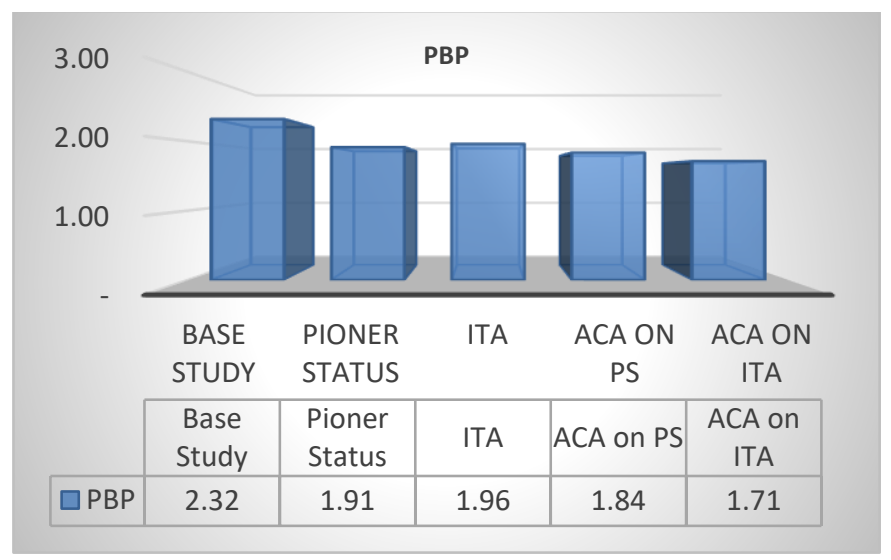

Figure 6. Pay Back Period results

\section{Conclusion}

In this study, the aim was to evaluate the role of government incentives on investment project of broiler contract farming in Peninsular Malaysia. The indicators of financial appraisal which is the capital budgeting analysis are computed using Present Net Value (NPV), Internal Rate of Return (IRR), Profitability Index (PI) and Payback Period (PBP). Regarding the primary analysis of financial feasibility, contract farms require more assistance to obtain a well profitable prospect in the chicken industry. Results show that with government tax incentives for the broiler contract investment, contract farming is a viable choice for broiler investment. With government tax incentives particularly the association between ACA and ITA, farms record improved financial indicators. We conclude that contract farming is a worthy choice for the farmers which should be recommended to gain higher profit. Finally, the government incentives have a significant impact on the project profitability. Thus, we would suggest that to increase profitability government should conceder such a policy and should imply the tax incentives especially the ones which rise the profitability such as Accelerated Capital Allowance (ACA) with Investment Tax Allowance (ITA). The government should re-strengthened the tax incentives model by giving access to all eligible broiler contract farmers for efficient utilization to improve their wellbeing and hence enhance the economy.

\section{Acknowledgments}

We acknowledge research grant (No: 5526015) from the Ministry of Education (MOE), Malaysia. Also, we express our thanks to the Department of Veterinary Services for the help and information they provided. Lastly, we express our thanks to all respondents who help us to complete the survey.

\section{References}

[1] M. The Department of Statistics. (2015, 4/1/2016). Available: https://www.statistics.gov.my/index.php?r=column/

[2] DVS. (2016, 23/12/2016). Department of Veterinary Services, Statistic Available: http://www.dvs.gov.my/

[3] M. Firdaus and L. Komalasari, "Feasibility Analyses of Integrated Broiler Production," Media Peternakan, vol. 33, 2011.

[4] S. S. Fahim, M. Maleki, and S. Yousefnezhad, "Effect of Intellectual Capital on Market Criteria in the Performance Evaluation of Accepted Companies in Tehran SEC," International Journal of Applied, vol. 3, pp. 79-88, 2013. D. Dayananda, Capital budgeting: financial apr
projects: Cambridge University Press, 2002.

A. Sekwat, "Capital budgeting practices among Tennessee municipal governments," Public Administration, vol. 30, p. 20.0, 1999.

R. Pike, "A longitudinal survey on capital budgeting practices," Journal of Business Finance and Accounting, vol. 23, pp. 79-92, 1996.

W. D. Cooper, R. G. Morgan, A. Redman, and M. Smith, "Capital budgeting models: theory vs. practice," in Business Forum, 2002, p. 15 .

J. Mackevičius and V. Tomaševič, "Evaluation of investment projects in case of conflict between the internal rate of return and the net present value methods," Ekonomika, vol. 89, 2010.

R. Slagmulder, W. Bruggeman, and L. van Wassenhove, "An empirical study of capital budgeting practices for strategic investments in CIM technologies," International journal of production economics, vol. 40, pp. 121-152, 1995.

L. Kengatharan, "Capital Budgeting Theory and Practice: A Review and Agenda for Future Research," Applied Economics and Finance, vol. 3, pp. 15-38, 2016.

C. M. Boardman, "The Role of the Payback Period in the Theory and Application of Duration to Capital Budgeting: A Reply," Journal of Business Finance \& Accounting, vol. 12, pp. 169-171, 1985.

[13] A. Malaysian Industrial Development. (2006). Incentives for Investment. Available: http://www.miti.gov.my/ 